\title{
COMMUNITIES PERCEIVED SOCIO-ECONOMIC IMPACTS OF OIL SANDS EXTRACTION IN NIGERIA
}

\author{
Murtala Ibraheem Chindo*
}

Geography Department, University of Leicester, Leicester LE1 $7 R H$, United Kingdom

\begin{abstract}
Nigeria is currently harmonising plans for the exploitation of oil sands in southern part of the country. The findings from a case study suggested that investment and subsequent production in oil sands could have positive outcomes, but could also affect the live standards of people in the surrounding communities. The current approach which excludes the communities in the planning process may only lead to trepidation of the crisis which has bedevilled the oil producing region of the country. There is the need to have an all-inclusive involvement of the affected communities in decision making process from initial conception through to the various stages of the mining cycle.
\end{abstract}

Key words: Mining, Oil sands, Communities, Socio-economic, Nigeria, Irele.

\section{Introduction}

Nigeria is not only the most populous country in Africa, but the major producer of oil in the continent. The political economy of Nigeria is based on the extractive industry (Orogun, 2010). Major mineral resources found in Nigeria include petroleum, natural gas and solid minerals. Oil from Nigeria accounts for 2.6 per cent of global production (BP, 2010:8), and the country is ranked the world's eleventh largest producer of crude oil (Energy Information Administration, 2010:2). As indicated in Figure 1, Nigerian onshore and offshore oil reserves are found in the Niger Delta region, the Bight of Benin, the Bight of Bonny and the Gulf of Guinea (Watts, 2008; UNDP, 2006). Nigeria currently produces about $\mathbf{2 . 5}$ million barrels per day of OPEC production. The discovery of substantial crude oil reserves in the deep and ultra-deep water was to increase the reserve base from 37.2 to 40 billion barrels by the end of 2010. In addition to oil wealth, an estimated 5.3 trillion cubic metres (TCM) of gas, reserves make Nigeria the world's seventh largest holder of natural gas reserve and the largest in Africa (USEIA, 2010).

Apart from oil and gas, Nigeria is endowed with solid mineral wealth that is found across the country. Davenport (2010) reported that the expansion of solid minerals mining has the potential to contribute 15 per cent to Nigeria's GDP by the year 2015. Currently, this

\footnotetext{
* Correspondence address:
}

Email:mic5@le.ac.uk sector, unlike oil, is non-developed, non-productive and currently contributes less than 0.5 per cent to Nigeria's GDP, as against 35 per cent from oil and gas in 2009 (National Bureau of Statistics, 2009). However, Nigeria is promoting the exploitation of non-oil minerals for additional revenue. Thus far, seven minerals are receiving priority attention for privatisation: gold, oil sands (bitumen), coal, iron ore, barite, lead/zinc and limestone.

Oil sand is a naturally occurring unconventional source of petroleum. It is a mixture of sand, clay or other minerals, water and heavy oil commonly known as bitumen. Oil sands are found in a number of countries with Canada and Venezuela having extremely larger quantities of reserve and production (Meyer, 2007). Oil sand was discovered in Nigeria in the early part of the $20^{\text {th }}$ century, but the resource was never exploited to date. Nigerian oil sands deposits estimated between 32-47 billion barrels occur within a belt that cuts across Edo, Lagos, Ondo and Ogun states (Ako, et al., 1983; Enu, et al., 1981; Iwuyemi, 1990; MMSD, 2010). Having realised the potential of the resource for import substitution and energy security, the government of Nigeria is putting several fiscal and policy measures for encouraging investment. Currently governed by the 2007 Minerals Act and supervised by the Ministry of Mines and Steel Development, the entire oil sands belt is delineated into three blocks (A, B, C). Block A is approximately 4,170 square kilometres; Block $B$ has not been demarcated for bid; and Block $\mathrm{C}$ is approximately 3,707 square kilometres (MMSD, 2010). 


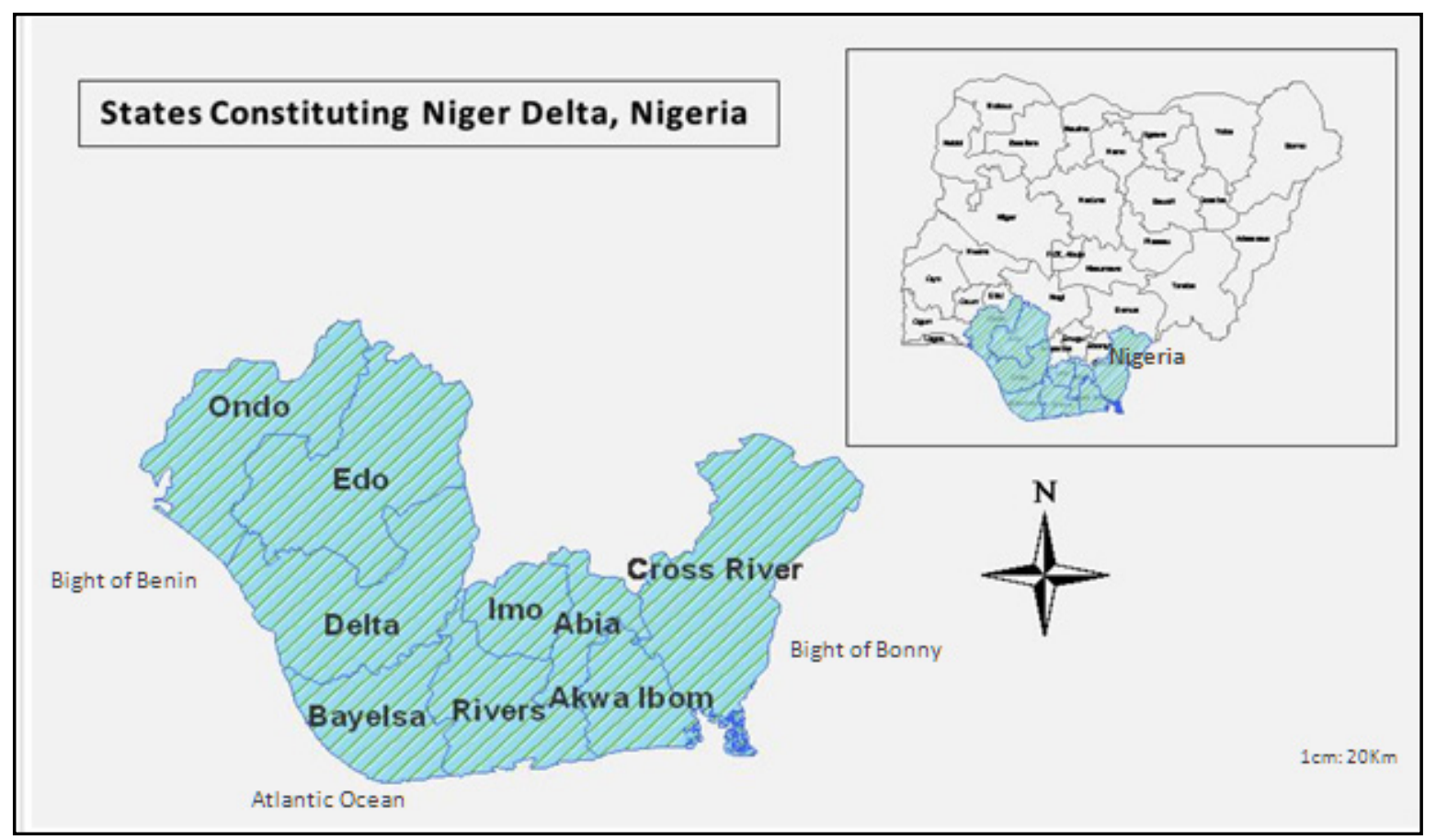

Figure 1. Nine states that make up the Niger Delta, Nigeria

The development of a large-scale oil sands industry can bring significant economic and social benefits for local communities and the country at large. Oil sands activities contribute to national economic growth and global energy security. Combined royalties and taxes received by government from companies could support health care, education, roads, power generation and infrastructure development. Investments in oil sands have a positive multiplier effect through promoting related industries such as housing, manufacturing, marketing, finance and insurance. It generates employment opportunities to people and servicing companies. Like all extractive activities, oil sands operations can have an adverse effect on the environment and the communities. There are documented evidences (e.g. Dan, et al., 2005; Environment Canada, 2009a; Levi, 2009; Rogner, 2000; Stosur, et al., 1998; Tenenbaum, 2009) of communities' lack of adequate compensation, loss of traditional land, loss of habitat (e.g. fish), destruction to migration routes and an increase in hunting activity. Health-related factors are vast, ranging from workplace accidents to pollution of freshwater. There is often an increase in levels of alcohol, drug consumption and violence from migrant workers. While Canada benefits from oil sands wealth, it grapples with most or all of the impacts mentioned above. The government now responds to issues raised by communities in the development of new oil sands projects due to the obvious impacts of decades of oil sands production. Nigeria, unlike Canada, is striving to develop its oil sands reserve without proper engagement of the existing communities.

Most of the previous research works on oil sands by individuals, organisations and groups in Nigeria have focused on the geology, mineralogy and method of processing (e.g. Adedimila, 2000; Ako, 1983; Iwuyemi, 1990). There is no doubt that these studies possess a lot of potential to scientifically evaluate the resources towards production. Even though these scientific production volume estimates are often fairly robust, much will be contributed to the present discourse and debate about the impacts of production if the perceptions of the potential host communities are brought into the planning processes. There is benefit that can be derived. First, the planning stage defines the parameters of any future impact of a mineral project on the surrounding communities and the pattern of host communities' involvement in that process is therefore of crucial importance. The perception of the people towards the emergence of new resources can be addressed systematically and in line with global best practices. Second, community perceptions and concerns are considered a part of the social and economic factors that condition new resource development. For example, opposition may rise due to perceived local social and environmental impact (Levi, 2009). Davis and Tilton (2005) also suggest that local communities tend to bear the negative impacts of mining - be they social, economical or environmental. The views of the locals who are the first to bear the negative impacts of resource extraction in Nigeria have been neglected. 
This paper is important at a time when Nigeria is developing its oil sands resources, and in a world where climate change, environmental issues, energy security (Bradshaw, 2010) and host communities development are firmly on the global policy agenda. Therefore, effective planning and decision making using bottom-up approach is advocated to address communities' needs in a better way. The top-down approach is only relevant in the implementation of decisions agreed upon with the communities (Roy and Ganguly, 2009). It is against this background that this study explores the perception and expectations of potential host communities on planned large-scale exploitation of oil sands in Ondo State. Generally, the perceptions of the community will depend on the role played by government, the extent of their engagement with the community and the pre-existing social conditions in the local community.

\section{Methodology}

Oil sands appear a potentially significant part of the local economy as Ondo State contains the largest number of exploration licences owned by both government and private investors. Irele, the selected local council of Ondo State has the largest number of oil sands demarcated areas. The local council has a total population of 144,136 (NPC, 2010), all lying within the oil sands exploration licenced area. The council occupies an area of about 1000 square kilometres with about 75 per cent of the populations engaged in agricultural activities. This implies that oil sands extraction will either co-exist or displace communities lying within the perimeter of the demarcated block and those in close proximity (Figure 2).

In this research, a case study strategy was adopted to understand how mining oil sands will eventually affect the lives of communities in proximity to areas of production. A combination of several data collection techniques including focus groups, documentary analysis and observation were used to ensure the collection of maximum amount of data in seven potential oil sands host communities in Irele local council: Ode-Irele, Legbogbo, Omi, Ajagba, Ijuba-Ijuoshun, Akingboju and River Ofoshuohu. Different geographical characteristics were taken into account in the selection of the study communities such as population, type of community (riverine, road community, remote, town), distance from potential mining activities and the proposed type of mining (surface or in situ). Chindo (2011) explains that these communities are typically small in size, remote and

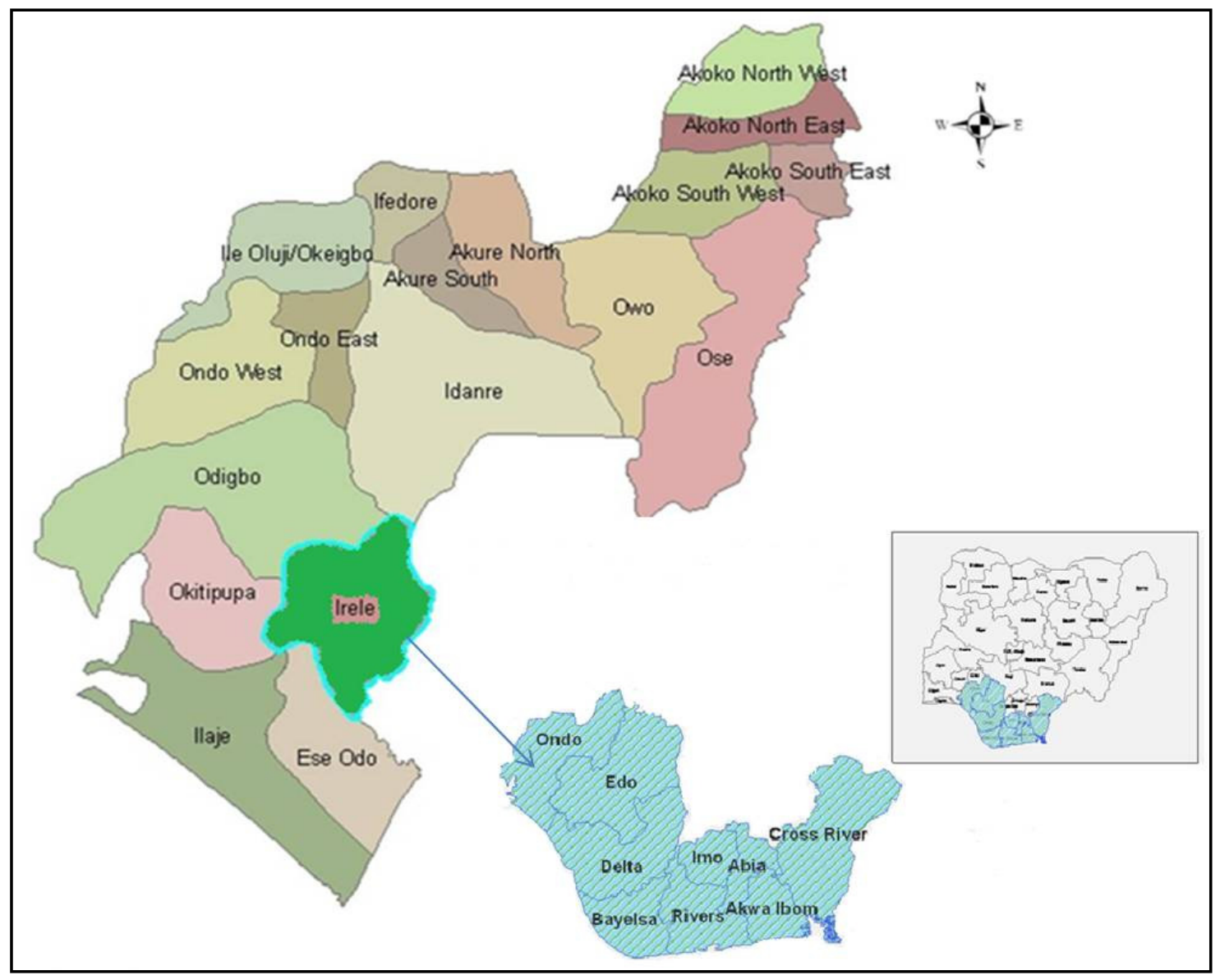

Figure 2. Map of the Niger Delta showing Irele Local Government Council, Ondo State 


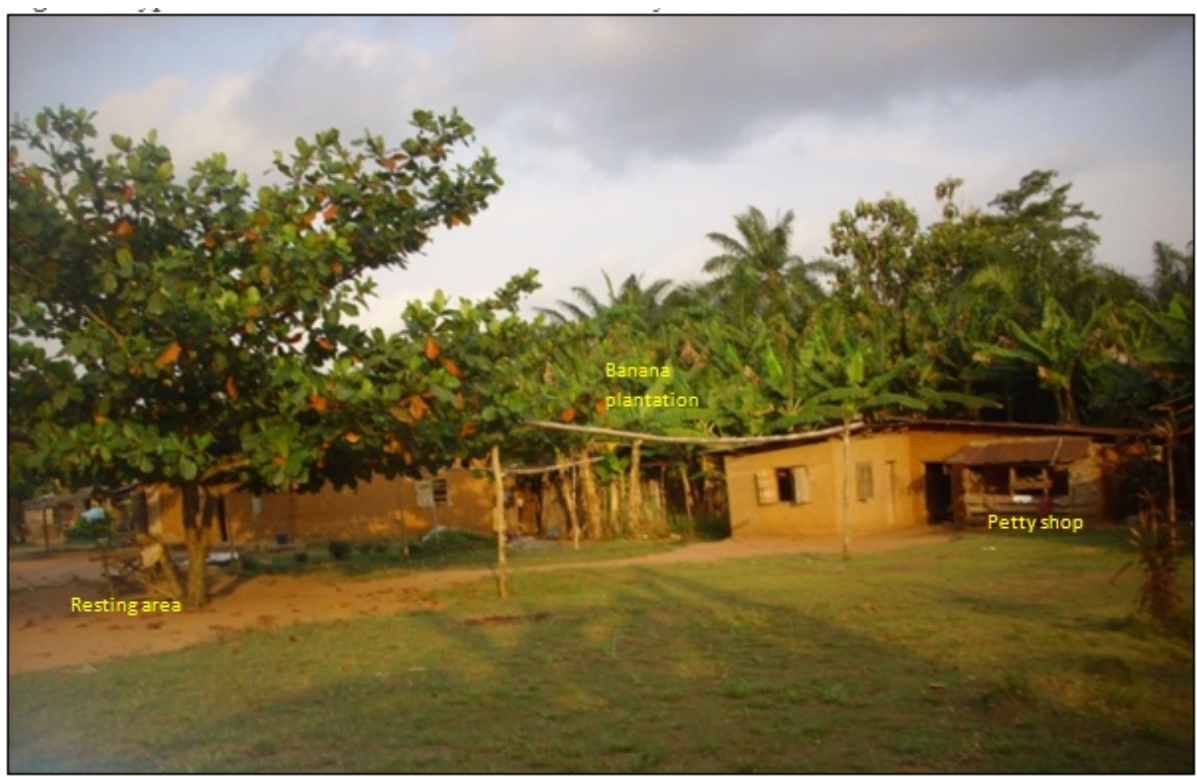

Photo 1. Typical settlements in a remote community

and how it affects the neighbouring communities. The site that hosted the ground breaking ceremony to flag-off the official commencement of oil sands exploration and exploitation by the former President of Nigeria in 2003 was also documented. These visits are in line with Yin's (1994) notion that sites visits are often useful in providing first hand information about a research goal. Similarly, public domain documents obtained included mining act and policy, technical reports, newspaper extracts, government

isolated, and dominated by a planned resourceextractive industry, whose activity would socially, economically and environmentally impact upon them (see an example of a remote settlement in Photo 1).

Focus group was the major method adopted to provide data from a group of people in the communities. There was nine sessions of focus group discussion: two at Ode-Irele involving youth and community leaders. The discussions at Omi and Ajagba consisted of community leaders only. The youths, some of who doubled as household heads were the participants at Legbogbo. Community leaders and children participated in River Ofoshuohu area. The situation at Gboge and Ijuba-Ijuoshun was different as the community leaders suggested that all community member consisting of women, community leaders, children and youths must be invited as a pre-condition for undertaken in the discussion. Given the volatile nature of the communities, such suggestions are taken into account while still maintaining a high sense of moderation in ensuring data accuracy. In each group session, the communities identified a number of factors they perceived beneficial and the problems they believed would emerge as a result of the oil sands project. The researcher moderated discussions but in certain cases, a local research assistant was engaged to assist in gaining access, and in breaking language barrier where participants are unable to deliberate in English language. The discussions were conducted in communal areas and held in slack times, mostly evenings, when the residents have returned from farms.

The researcher follow amorphous pattern of observation but with relevance to the purpose of the research. Information was documented about the natural discharge of natural bitumen to the surface pronouncements and reports. Internal documents that are less visible such as plans and proposals were also obtained. Documents, either archived or recent, were obtained from ministries, departments and agencies (MDAs) of government, private consultants and development organisations.

Data gathered from the above methods were first transcribe and analysed using qualitative software, Nvivo 8. In order to generate categories and present the findings as themes, various codes/nodes around a common word (tree-node) with greater explanatory power was adopted. A set of queries were generated to link the responses from various methods and communities. The themes that have emerged from this analysis are presented for discussion, and choice quotes served to provide greater depth of understanding or to articulate individual opinion. For ethical reasons, pseudonyms/codes are used in the text for participants, and where consented names are mentioned.

\section{Findings and Discussion}

The communities' perception of oil sands-related social problems and their expectations have strongly influenced their receptiveness of and attitudes towards governance of oil sands. However, there is variance in priorities set by communities as to potential benefits and costs. Loss of land for agricultural purposes, the fear of displacement, rising costs of living and crime were generally considered negative, while the provision of infrastructure for health and education, business opportunities, increased personal income and job creation were considered positive. 


\section{Positive Socio-economic Impact}

\section{Provision and Improvement of Infrastructure and Social Amenities}

The availability of basic amenities and infrastructure in a community would add value and increase the aesthetic look of the communities; and support the community's need for social interaction, as well as contribute to the physical well-being and material comfort of local people. The major infrastructure facilities in this regard are roads, electricity, education, health, pipe-borne water and recreation facilities. However, variation in the provision of infrastructure among the communities is noticeable. Legbogbo, Omi and Ajagba located on the tarred roads already have at least basic infrastructure and social amenities, while remote communities, such as Ijuba-Ijuoshun, riverine areas and Gboge lack these amenities. Primary schools are the common to the communities; however, tertiary institution is not available in any of the communities. Pipe-borne water, fire services, recreational media and hospitals are not commonly available, except in Ode-Irele.

In terms of educational facilities for example, Ode-Irele, Omi and Ajagba have a range of nursery, primary and secondary schools run by government and private individuals. Schools in these communities more often than not have a shortage of teachers, and lack instructional materials such as chairs and books, apart from being too small for the growing population of school-going children. Perceptions of the provision of health care facilities to the communities reflect the current non-availability of health facilities, particularly in remote areas. Health facilities such as hospitals, dispensaries, and health centres are not widely dispersed and are inaccessible to remote Gboge and Ijuba-Ijusoshun communities. Primary health care centres for maternal and child health is neither accessible nor affordable to the people in remote communities as they have to travel long distances to access one. In the process the patient is either lost or develops infections:

Last year we lost women during birth because of labour complications that our traditional birth attendant is unable to handle. During the over 10 kilometre journey they gave up the ghost.

(Gboge Community Elder C, Pers. Comm., 2010)

The communities not connected to an electricity power supply are upset to have been left out in development process. Youths in Legbogbo were aggrieved that their community is not being considered for the provision of electricity even though high tension electric cables have passed through the village to supply power to towns like
Ode-Irele. On the other hand, Ijuba-Ijuoshun community contributed money to install a power generator which is being fuelled and serviced by the villagers.

All communities recognised that the failure of government to provide amenities was seen as a purely a political issue, and a lack of concern for the rural people. Therefore, they (the communities) anticipate with enthusiasm that the coming of oil sands can at least provide some basic infrastructural facilities. Participants in all the communities believe strongly that investor's corporate responsibility policy will have a very positive impact on the quality of education children are receiving by employing more teachers, together with providing up to date instructional materials and books. These findings about perceived infrastructure benefits to oil sands host communities support the argument of Bridge (2004) that new mining communities are potential beneficiaries of a wide range of new social services, as well as access to better education, health and water.

\section{Enhancement and Prosperity of Businesses}

The communities believe that all the phases of oil sands mining can boost economic activity and create opportunities. Business enterprises, such as banks and mining equipment sellers opened-up offices in Akure, the state capital, in anticipation of increased economic activities when pronouncement was made by government at the ground breaking ceremony in 2003. Unfortunately, the companies had to close down because of lack of activity. The contribution of mining oil sands to the rise of businesses was viewed positively in all the local communities. Generally group discussants were of the opinion that oil sands extraction would create an avenue for petty trading of agricultural products and increase local businesses for artisans and traders of non-farm products to a greater extent - by so doing, the economic potentials of remote communities would be manifest. For example, Ijuba-Ijuoshun and Gboge do not have local stores, but items are usually sold in a tray or on a table in front of a house. The arrival of people in search of jobs would certainly increase demand for food and other goods, thus increasing pressure on the local people to produce more food crops to sell. There was general consensus among communities that apart from local shops and petty trade opportunities, contractors and construction companies working for the oil sands company will establish a base in their localities. There will be demand for more local manufacturing of cutlasses by artisans, because of increase in demand for cutlasses that will be used in cutting/clearing trees: “...even our blacksmiths can be able to produce more cutlasses, so that people can buy, and use it to cut grass for the oil sands 
companies" (Youth, Pers. Comm., 2010). A different argument concerned the sustainability of businesses after mine closure, when compared to the conditions surrounding traditional farming. Indeed, mining communities that have abandoned their primary economic activity to mining are left with hardly any other alternative employment opportunities, and suffer economic and social upheavals when the mines close (Abdel-rahman, 2000).

The riverside communities are optimistic that oil sands extraction would offer the chance for fish markets to expand. Fresh, smoked and fried fish will be prepared and sold to both miners and locals for consumption as a source of protein. If the fish market was boosted, local boat manufacturers would construct more boats for fishing, thus expanding their businesses. From this perspective, Auty (2006:136), however, argue that domestic expenditure from mining employment stimulate little economic activity - below communities' expectations.

\section{Job opportunities}

The traditional economic base in the case study, as with any other rural economy, is agriculture. Men and women, both young and old, are engaged in direct farming using local/primitive tools. In nearly all the communities, a large number of people are engaged in farming as their means of livelihood and source of food and petty income. Riverine areas engage in both fishing and farming. At Irele, Omi and Ajagba, a part of the young population earn a living by engaging in commercial motorcycle business (commonly referred to Okada), transporting people and goods from the remote areas. The rural communities also engage in multiple jobs; a farmer is able to grow crops and harvest fruits and tap palm wine concurrently. This might be as a result of the limited land available for full-scale farming to the growing population who have to share what communal land there is available.

There is a belief that investment in oil sands extraction would provide opportunity for employment in non-farm activity and encourage local economic growth. Employment by an oil sands company allows individuals to take care of themselves; it can also:

...provide the money that will use to carter for our families. For now, there is nothing to do apart from farming, and one cannot go out of the village to look for other jobs because of limited education. So if employed even as labourers it is better [than nothing]

(LG Youth Leader, Pers. Comm., 2010)

New oil sands operations are expected to create local and regional jobs. The local communities anticipated direct employment with oil sands extraction companies and considerable indirect employment with contractors and servicing companies. The construction phase that follows exploration involves many activities, which requires both skilled and un-skilled labour in which the local population can be engaged on a short-term basis. As activity progresses to production, long-term contracts require mainly skilled and semi-skilled workers; thus limiting the chances of local labour supply. This perception, however, becomes difficult to substantiate, in view of the fact that oil sands employment is yet to begin. HRH Obalo Adesayo of Ajagba land affirms: “...oil sands development comes with benefits especially employment opportunities to our youths and outsiders, even though they are not highly educated" (Pers. Comm., 2010). The desire of local youth for employment and related economic advantage support their receptiveness to the oil sands project despite the very real threat of environmental degradation.

\section{Poverty Alleviation and Increased Personal Income}

An investigation using the focus groups to determine the income characteristics was particularly difficult as participants have no full understanding of their earnings from farm products. Generally, records of income from the sale of farm produce are not kept and the participants had to struggle with their memories to estimate the income earned. The figures quoted (ranging from $\$_{5-12}$, ooo) in the remote communities are generally less than the national minimum wage of 18 , ooo (US\$120) per month, and less than the one dollar (equals 150 Nigerian Naira) per day benchmark of reducing poverty and hunger stipulated by the Millennium Development Goal One.

Any income earned from oil sands employment or businesses will be spent on buying goods and services produced by the same local people, which in turn, would boost the income of the people in the community. Incomes also provide the additional incentive for being able to fund funerals, weddings and other ceremonial events, as individuals or as a community:

It will bring the money that people can use to take care of their families much better - buy cloth and send them to schools; otherwise with poverty one will be unable to marry (Laughed). The remaining money can be used to help our community to buy like tractor or modern farm equipments for our own good

(IJ Youth,, Pers. Comm., 2010). 
Increased income to members of the community would promote collaboration for community development. In the past, the Gboge community struggled through communal efforts to raise money to repair the roof of a primary schools damaged by the helicopter of a Canadian oil sands company (JERES). The uncertain nature of local earnings makes it impossible to set a fixed amount of money as monthly contribution for the execution of communal projects, such as drilling a well for water supply during the dry season. Youths in Legbogbo indicated that even though agriculture accounts for nearly the total income of a particular individual or household, the selling of food crops and menial businesses can complement income from farm activities.

\section{Perceived Socio-economic Problems}

Local communities agreed that just as oil sands extraction could bring a number of positive benefits; adverse negative impacts on their social and economic setting might also be felt. Numerous problems that would affect the individual, family and community are therefore envisaged if oil sands project comes into being. Indeed, the general consensus among communities is that every development activity, oil sands not an exception, could result in some undesirable conditions, apart from deformity of the surrounding. This submission tallies with Bridge (2004:246) argument that: "aesthetic and physical safety concerns have been progressively supplemented by struggles over the impacts of mining on human health, agricultural productivity, and ecosystem function".

\section{Loss of Communal Land for Farming}

Oil sands extraction involves the appropriation of huge swathes of indigenous lands, and displacement of communities within the mining licence area, when, in fact, local people depend on the land as a major source of food and income. In reality some communities are still surviving, despite that oil sands is limiting, and in the extreme, preventing farming activities. This claim was confirmed during a visit to Agbabu area, where the outflow of oil sands in past drilling site has affected large areas of farming land and ecosystems. The long-term implications of loss of land for the individuals, family and community put them at an immediate disadvantage of having to face food insecurity, increased poverty and degradation of environmental resources. Community leaders of the area are worried that loss of land would severely impact on the people. Chief Bayo Ogunje, for instance queried the insincerity of government in promising compensation citing instances where communities were short changed and left in limbo: If agricultural land that contributes immensely to the economic well-being of our people is taken, what is the guarantee compensation will be given at all and will it equal farming?

In Nigeria, the allocation of land to individuals and organisations for residential, agriculture and commercial purposes is guided by the 1979 Land Use Act. By this law, communal land can be transferred or forfeited based on 'public interest' to another body for commercial development; for example, mining (Land Use Act, 1979). The transfer of land for mineral operations can be appropriated for use by foreign and local mining companies, while limiting local communities to compensation for the value of the revoked land. Community leaders alleged that the Land Use Act and other legal provisions of mineral ownership have completely relegated them from participation in the governance of oil sands extraction, and that they are left to bear the consequences. On numerous occasions, reference was made to the difficulties faced by oil communities in Niger Delta.

\section{Possible Displacement, Resettlement and Compensation}

In principle, oil sands extraction, like any other mining activity, requires a given area of land to excavate, which causes a significant change to the landscape and affects agricultural soils, and the related intense activity leads to the displacement of land and people. In fact, Gboge community is aware of relocation plans from the drilling companies that visited the community in the past (Community elder): "they will move us away from here; they have been saying it that, they will move people away from here" (Pers. Comm., 2010).

Opinions vary on the willingness of communities to be displaced and resettled. Community leaders are willing to assist in the relocation of people if absolutely necessary, but: relocation should respect the rights of the communities and should follow proper procedures, not in an exploitative manner as was the case in the Niger Delta when oil drilling started. The communities should consent to, and be fully informed about, any planned relocation. The women in Ijuba-Ijuoshun and Gboge vehemently objected to the idea of relocation, arguing: what happens if farms and crops are all destroyed and the new land is not as productive and as vast as the former land?

The riverside area fears that inadequate compensation signifies that their means of subsistence (fishing) would be taken away and the community would be left in a state of uncertainty and loss. Gboge would resist land acquisition without fair compensation. Therefore, fair compensation 
entitlements to both land owner and tenant should be set according to the procedures stated in the Land Use Act 1979 and Mining Act, 2007. The value of the land should be compensated to the land owner while the financial worth of the properties or crops/plantation which exists on the land goes to the tenant in cases of land lease, based on the prevailing market value. Adequate compensation can be achieved by surveying and documentation of genuine land owners; however, caution must be taken of land speculators that have started making false claims by carrying out their own surveys in secret, including quietly surveying lands belonging to other people.

\section{Proliferation of Social Vices, Crime and Violence}

Local communities are able to stay safe from armed bandits and robbers on the grounds that vigilante groups (voluntary local law enforcers, made up of mainly hunters) and deities safeguard life and property especially in Gboge, Ijuba-Ijuoshun and Legbogbo where there is the absence of state law enforcement agents. The fear for the proliferation of crime as migrants from various social backgrounds arrive to participate in oil sands operations was a source of worry. In such instances there is little the vigilante can do to maintain law and order, hence the need for local police. Remote communities use their traditional justice system to decide about civil cases and deliver appropriate punishment based on customs for minor offences; serious cases such as murder are referred to the police and local authority by the committee of elders.

It appears a common theme that oil sands mining can result in some anti- social activities that are intolerable to the communities. The influx of foreign and non-local migrants to the communities bring banditry, alter local lifestyle, and increase competition for existing natural resources. The Omi community leader have observed that the community is relatively safe from robbery at present, but worried that mining comes with the threat of petty theft, and assault on mine workers and the local people. Despite the fact that traditional rulers have very limited control over migrants, they are nonetheless unwilling to condone any act of abomination or sacrilege within the community. To buttress this view elsewhere, Gibson and Klinck's (2005) study of indigenous communities in Canada indicates that income earned from oil sands employment have also led to detrimental negative social impacts such as alcoholism and drug abuse. Ijuba-Ijuoshun and Legbogbo communities, however, hold the conviction that any violent crime is likely to be committed by an outsider, and not by a member of the communities.

The fear of women regarding promiscuity in the mining industry was given empathy. Concern was born out of the stories heard about how young females attract male oil workers. Migration of young ladies in search of men rather than jobs increases prostitution and the spread of sexually transmitted diseases and HIV/AIDS. This happens especially when jobs separate men from their families for a long period of time. Separation from the family was seen as less of a problem to the youths from Legbogbo because mine employees could spend their off-period at home with the family. As such, the issues raised regarding the repercussion of unfaithfulness would be minimised.

Other areas of concern to the communities are about the effects of the destruction of their protected areas particularly places of worship and ancestral homes of their deities. Accordingly, such ancestral homes not only serve as places of worship, but bring about social cohesion and serve as recreational spots for yearly events such as the yam festival - an annual celebration to mark the end of a farming season, which socially and spiritually unite the communities.

\section{Conclusion}

The findings of this study has shown that understanding perceptions about the social and economic aspects of opening a new oil sands extraction provides a foundation from which to consider how a mining project impacts a community. Ideally, identifying community attitudes, perceptions and expectations should be undertaken during the planning stage of a project. This activity will ensure that consultation, participation and dialogue is maintained in the design and implementation of development plans and processes that respond to and prioritise local developmental needs, while achieving the national goal of revenue generation.

This is particularly relevant in the study area, given their close proximity to exploration licences and other land uses. As relocation and related compensation is the overwhelming fear of the communities, it is anticipated that the Mineral and Land use Acts are followed through in issues of compensation and relocation. The sustainability of these communities will be partially dependent on the provision of infrastructure, job creation and opportunities for businesses and trainings.

Relying on the experiences of resource development in Nigeria (mainly oil and gas), any approach to resource extraction without understanding the socio-economic impacts on host communities will not be a success. If such issues are not taken into context, it would be a parallel to what is happening in the Niger Delta. The oil sands development question calls for an in-depth and integrated analysis of environmental, socio-economic 
and political perspective in planning so as to reduce tension, and to create a framework for local-national development and sustainability. Specifically, socioeconomic factors should assume equal ratio of assessment in the conduct of impact assessment by government and investors for permitting, monitoring and evaluation purposes.

\section{Bibliography}

Abdel-Rahman, H 200o, 'Multi-firm city versus company town: A micro foundation model of localization economies', Journal of Regional Science, vol. 4, p.755-769.

Adedimila, AS 2000, Bitumen: Nigeria's other black gold, viewed on 20 February 2011, http://www.nuc.edu.ng/nucsite/File/Inugural\%2oLecture /ILS-11.pdf.

Ako, B 1983, 'Strategies for the exploration of tar sands' in B Ako \& E Enu (eds) First workshop on Nigerian tar sands.

Auty, RM 2006, 'Mining enclave to economic catalyst: large mineral projects in developing countries', Brown Journal of World Affairs, xiii, p.135-145.

BP (British Petroleum) 2010, BP statistical review of world energy 2010, British Petroleum, London.

Bradshaw, MJ 2010, 'Global energy dilemmas: a geographical perspective', Geographical Journal, vol. 176, p.275-290.

Bridge, G 2004, 'Contested terrain: mining and the environment', Annual Review of Environmental Resources, vol. 29, p.205-259.

Davenport, J 2010, 'Nigeria aiming to grow mining's GDP contribution to $15 \%$ by 2015 ', Mining Weekly, viewed on 20 April 2010, http://www.miningweekly.com/article/nigeria-to-growmining-sector-to-15-of-gdp-by-2015-2010-03-05.

Davis, G \& Tilton, J 2005, 'The resource curse', Natural Resources Forum, vol. 29, p.233-242.

Energy Information Administration 2010, International petroleum (Oil) production: OPEC countries crude oil excluding lease condensate, Energy Information Administration, Washington DC.

Environment Canada 2009, National pollutant release inventory 2007 summary - 3.1.1.1 Criteria air contaminants, viewed on 14 May, 2009, http://www.ec.gc.ca/inrpnpri/default.asp?lang=En\&n=oD 743 E97-1.

Gibson, G \& Klinck, J 2005, 'Canada's resilient north: the impact of mining on aboriginal communities', Pimatisiwin, vol. 3, p.116-139.

Iwuyemi, A 1990, 'Bituminous tar sands development and utilisation in Nigeria: some economic considerations' in: The Nigerian Mining and Geosciences Society, ${ }_{1}^{\text {st }}$ Workshop on Nigerian Tar Sands, Ago-lwoye, Nigeria.
Land Use Act 1979, Laws of the Federal Republic of Nigeria, viewed on 05 November 2009, http://www.nigerialaw.org/Land\%2oUse\%2oAct.htm.

Levi, MA 2009, The Canadian oil sands: energy security vs. climate change, Council Report, 47, New York, Council on Foreign Relations.

Meyer, R, Attanasi, E \& Freeman, P 2007, 'Heavy oil and natural bitumen resources in geological basins of the World', US Geological Survey Open-File Report 2007-1084, viewed on 10 July 2009, 3-36 p., http://pubs.usgs.gov/of/2007/1084/.

Ministry of Mines and Steel Development 2008, Solid minerals sector: our 34 minerals, Abuja, MSMD.

Ministry of Mines and Steel Development 2010, Tar sands and Bitumen, Abuja, MSMD.

National Bureau of Statistics 2010, Revised 2009 and estimates for Q1- Q3, 2010 Gross Domestic Product for Nigeria, Abuja, NBS Headquarters.

NPC (National Population Commission) 2010, National and state population and housing tables: priority tables, 1, pp.163-231, Abuja, NPC Headquarters.

Orogun, PS 2010, 'Resource control, revenue allocation and petroleum politics in Nigeria: the Niger Delta question', GeoJournal, vol.75, p.459-507.

Rogner, H 2000, 'Energy resources', in: J Goldemberg, (ed). World energy assessment: energy and the challenge of sustainability, UNDP/UN-DESA/World Energy Council, pp.142.

Roy, AR \& Ganguly, M 2009, 'Integration of top down and bottom up approach in urban and regional planning: West Bengal Experience of Draft Development Plans and beyond', Proceedings of the National Town and Country Planners congress, Goa, India.

Stosur, G, Waisley, SL, Reid, TB \& Marchant, LC 1998, 'Tar sands: technologies, economics, and environmental issues for commercial production beyond the year 200o', in:

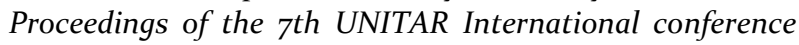
on heavy crude and tar sands, Paper 1998.002, Beijing.

Tenenbaum, D 2009, 'Oil sands development, a health risk worth taking? Focus oil sands development', Environmental Health Perspectives, vol. 117. nr.4, p.150-155.

United Nations Development Programme (UNDP) 2010, Human Development Report: the real wealth of nations: pathways to human development, New York, Palgrave Macmillan for the United Nations Development Programme, 162-191.

USEIA (United States Energy Information Administration) 2010, International petroleum (Oil) production: OPEC countries crude oil excluding lease condensate, Energy Information Administration, Washington DC.

Watts, M 2008, Curse of the black gold. 50 years of oil in the Niger Delta, Powerhouse Books, New York.

Yin, RK 1994, Case study research: design and methods, $\left(2^{\text {nd }}\right.$ ed.), Sage Publications, Beverly Hills, CA. 